\title{
Analysis of the observed rainfall intensities in the territory of the Eastern Slovakia
}

\author{
Adam Repel ${ }^{1}$,Martina Zeleňáková1, ${ }^{1,}$, Slávka Galas², Helena Hlavatá ${ }^{3}$ \\ ${ }^{1}$ Institute of Environmental Engineering, Faculty of Civil Engineering, Technical University of \\ Košice, Vysokoškolská 4, Košice, 04200, Slovakia \\ ${ }^{2}$ AGH University of Science and Technology, Department of Environmental Analysis, Geological \\ Mapping and Economic Geology, al. Mickiewicza 30, 30-059 Krakow, Poland \\ ${ }^{3}$ Slovak Hydrometeorological Institute, Branch Office Košice, Košice 041 17, Slovakia
}

\begin{abstract}
Climate change has a significant impact on many sectors, including water management. A very important parameter in the designing of water management objects and systems (for example sewers, water retention facilities etc.) is rainfall intensity, which expresses the amount of precipitation per time. In Slovakia, the design values of rainfall intensities from 1973 are still in use. These values are outdated and probably currently unsatisfactory. This paper is focused on analysis of observed rainfall intensities in the territory of Eastern Slovakia. Observed rainfall data of 10 minutes' rainfall for time period 2000-2018 was compared to design values of rainfall intensities from 1973. The data from two rainfall station Poprad and Košice were considered. In the paper, there are compared observed (measured) and designing rainfall intensities for the duration of rain 10, 30 and 60 minutes.
\end{abstract}

\section{Introduction}

Climate change impact related to water resources can be characterized by changes in temperature and precipitation. The rainfall Intensity Duration Frequency (IDF) relationship is a mathematical relationship between the rainfall intensity, the duration and the return period [1]. For designing of rainwater sewage system is the most important parameter the atmospheric precipitation. According to origin we recognize rainfall: from heat (convective), orographic and cyclonal. Depending on the amount of precipitation and their duration or according to the proportion of these two characteristics, called intensity, rainfall (rain) is divided into normal and extreme, where extreme rainfall is the most important for designing of rainwater management systems [2]. Rainfall intensity is the most important parameter in the design and calculation of rainwater management, as it reflects the maximum amount of rainwater that needs to be drained off during the rain event [3]. Design rains are used for calculation the design run off. Design rain represents the intensity profile of the rain characterized by a statistically determined periodicity [4]. The design rain is characterized by intensity $I$ (height of the water layer that hits the earth's surface in a

\footnotetext{
*Corresponding author: martina.zelenakova@tuke.sk
} 
certain time), duration $T$ and period of repetition (years) [3]. Design rain is used as parameter to design sewers and drainage systems in urban areas. Only those rains that are relatively short and extremely heavy are considered as significant - these rains are called heavy rains. Parameters of heavy rains (duration, height of rain and intensity of rain) according Berg [5] are in Table 1. It means, rain with duration 10 minutes is heavy rain, when its intensity is more than $0.5 \mathrm{~mm} / \mathrm{min}$ [5].

Table 1. Description of heavy rains according to Berg [5].

\begin{tabular}{|l|c|c|c|c|c|c|c|c|c|}
\hline Duration (min) & 5 & 10 & 15 & 20 & 25 & 30 & 45 & 60 & 120 \\
\hline $\boldsymbol{H}(\mathbf{m m})$ & 2.5 & 3.8 & 5.0 & 6.0 & 7.0 & 8.0 & 10.25 & 12 & 18 \\
\hline $\boldsymbol{I}(\mathbf{m m} / \mathbf{m i n})$ & 0.5 & 0.38 & 0.33 & 0.30 & 0.27 & 0.27 & 0.23 & 0.2 & 0.15 \\
\hline
\end{tabular}

Rainfall intensity is the amount of rainfall over a period of time. In principle, the higher the maximum intensity of a rain is, the less is its duration - in other words, the shorter the rain is, the greater is its intensity [6]. Statistical methods can be used to express the rainfall intensity of precipitation events with different periodicities. The most important are short rains with duration from 10 to 60 minutes with periodicities from 0.1 to 5.0, where periodicity 0.1 means, that the occurrence of rain with such intensity is once every 10 years and periodicity 5.0 means occurrence of rain 5 times a year [3].

Many intensity calculation formulas are used in worldwide. In Poland, the Blaszczyk formula is used, in Germany the Reinhold formula is used and in United states is used for example Wenzel formula [7]. The first analyses of rainfall in Slovakia order to derive rainfall intensities were carried out by Dub in 1945. Next analysis was done by Rosik, Čižek or Trupl [5]. The most extensive research in the field of rain intensities in Slovakia has been carried out by Šamaj and Valovič in 1973. They analysed data from 68 ombrographic stations in Slovakia. The paper presents result of processing of rain for 5 to 180 minutes with different probabilities of occurrence. The length of the observation series was different, the average was 20 years [8]. The results of the work of Šamaj and Valovič are still used in engineering practice in Slovakia, especially in the calculation of design rain in the design of sewer systems and rainwater management systems. For the design of the rainwater sewers, an intensity of rain with duration 15 minutes and a probability of occurrence $p=0.5$ (every two years) shall be considered [9]. Next analysis in this field of study were done by Faško [10], Cebulak [11], and Kohnova [12]. They bring some results, but values of intensities by Šamaj and Valovič are still used in Slovakia.

In the context of climate change, a significant decrease in the number of rainy days and a significant increase in the precipitation intensity values have been identified in many places in the world, for example in Italy by analysis of rainfall data from 1951 to 1996 has been proven that the trend for the number of wet days in the year is significantly negative throughout Italy [13]. Similar results were published in results of research throughout China, where slightly decreasing trend in daily precipitation from 1956-2000 were observed, but on the other hand, significant decrease in the number of rainy days and increasing of precipitation events with high intensity were observed [14].

It is evident from the above-mentioned knowledge that there is a hypothesis of a change in rainfall intensity in Slovakia since 1973. In this paper, precipitation events in the years 2000-2018 are analysed in order to verify the correctness of precipitation intensity values by Šamaj and Valovič from 1973. 


\section{Materials and methods}

\subsection{Study area}

In the paper, data from two rainfall stations (Poprad and Košice) in the eastern part of Slovakia are used. The location of both precipitation stations is shown in Figure 1. Poprad city is situated in altitude of $672 \mathrm{~m}$ in western part of eastern Slovakia in mountain region close to the highest mountains of Slovakia, the High Tatras. Climate in this city is affected by topography of the terrain [15]. Košice is city situated in central part of eastern Slovakia near Hornád river in altitude of 208 m [16].

\subsection{Data and methodology}

Data used for this study consist of automatically recorded 10 minutes' rainfall data for time period 2000-2018 in Poprad station (19 years of observation) and time period 2003-2018 in Kosice station (16 years of observation). Data were obtained from the Slovak Hydrometeorological Institute, regional center Kosice. There are no missing data in datasets, precipitation from all 10 minutes' intervals are included. From 10 minutes' precipitation data, the 30 - and 60-minutes precipitation values for each station was gained and analyzed.

In this work, the number of exceedances of the rainfall intensities set by Šamaj and Valovič for different periodicity and different durations of rain were found. Periodicity 5.0 means the occurrence of rain with a given intensity 5 times a year (similar with periodicity 1.0 and 2.0) and periodicity smaller than 1 , for example 0.2 means the occurrence of rain with a given intensity once every five years. For each year was found rainfall events with higher intensity, than intensity by Šamaj and Valovič, stated in the Table 2. Numbers of exceedances were written to the table and results were evaluated. For designing of rainwater sewage system is the most important rain with short duration (10 and 30 minutes) and with periodicity 0.2 .

Table 2. Rainfall intensities (in $\mathrm{mm} / \mathrm{min}$ ) by Šamaj and Valovič for different periodicities and durations of rainfall for Poprad and Košice station.

\begin{tabular}{|c|r|r|r|r|r|r|}
\hline & \multicolumn{4}{|c|}{ Košice } & \multicolumn{4}{|c|}{ Poprad } \\
\hline \multirow{3}{*}{ Periodicity } & \multicolumn{4}{|c|}{ Duration of rain (minutes) } \\
\cline { 2 - 7 } & $\mathbf{1 0}$ & $\mathbf{3 0}$ & $\mathbf{6 0}$ & $\mathbf{1 0}$ & $\mathbf{3 0}$ & $\mathbf{6 0}$ \\
\hline $\mathbf{5 . 0}$ & 0.62 & 0.27 & 0.15 & 0.48 & 0.22 & 0.13 \\
\hline $\mathbf{2 . 0}$ & 0.89 & 0.40 & 0.22 & 0.67 & 0.32 & 0.19 \\
\hline $\mathbf{1 . 0}$ & 1.10 & 0.50 & 0.28 & 0.83 & 0.40 & 0.24 \\
\hline $\mathbf{0 . 5}$ & 1.28 & 0.60 & 0.34 & 0.97 & 0.51 & 0.30 \\
\hline $\mathbf{0 . 2}$ & 1.55 & 0.73 & 0.42 & 1.19 & 0.65 & 0.38 \\
\hline $\mathbf{0 . 1}$ & 1.74 & 0.84 & 0.48 & 1.37 & 0.76 & 0.44 \\
\hline
\end{tabular}

\section{Results and discussion}

Number of exceedances of the rainfall intensities set by Šamaj and Valovič in observed years are shown in Table 3 in Poprad station and in Table 4 in Košice station. For each year, periodicity and duration of rainfall, there is number of occurrences of rainfall with an intensity greater than intensities by Šamaj and Valovič, stated in Table 2. 
Table 3. Number of exceedances of the rainfall intensity set by Šamaj and Valovič for the observed years in Poprad station.

\begin{tabular}{|r|r|r|r|r|r|r|r|r|r|r|r|r|r|r|r|r|r|r|r|}
\hline Periodicity & \multicolumn{3}{|c|}{5.0} & \multicolumn{3}{|c|}{2.0} & \multicolumn{1}{|c|}{1.0} & \multicolumn{3}{|c|}{0.5} & \multicolumn{3}{|c|}{0.1} \\
\hline $\begin{array}{l}\text { Duration } \\
\text { (min)/Years }\end{array}$ & $\mathbf{1 0}$ & $\mathbf{3 0}$ & $\mathbf{6 0}$ & $\mathbf{1 0}$ & $\mathbf{3 0}$ & $\mathbf{6 0}$ & $\mathbf{1 0}$ & $\mathbf{3 0}$ & $\mathbf{6 0}$ & $\mathbf{1 0}$ & $\mathbf{3 0}$ & $\mathbf{6 0}$ & $\mathbf{1 0}$ & $\mathbf{3 0}$ & $\mathbf{6 0}$ & $\mathbf{1 0}$ & $\mathbf{3 0}$ & $\mathbf{6 0}$ \\
\hline $\mathbf{2 0 0 0}$ & 3 & 4 & 3 & 3 & 2 & 2 & 1 & 2 & 2 & 0 & 0 & 0 & 0 & 0 & 0 & 0 & 0 & 0 \\
\hline $\mathbf{2 0 0 1}$ & 7 & 9 & 10 & 5 & 4 & 6 & 2 & 1 & 3 & 1 & 0 & 1 & 1 & 0 & 0 & 0 & 0 & 0 \\
\hline $\mathbf{2 0 0 2}$ & 7 & 9 & 9 & 4 & 6 & 7 & 2 & 3 & 4 & 1 & 1 & 2 & 1 & 1 & 1 & 1 & 1 & 0 \\
\hline $\mathbf{2 0 0 3}$ & 2 & 2 & 2 & 1 & 2 & 1 & 0 & 0 & 0 & 0 & 0 & 0 & 0 & 0 & 0 & 0 & 0 & 0 \\
\hline $\mathbf{2 0 0 4}$ & 2 & 5 & 8 & 2 & 3 & 3 & 2 & 0 & 2 & 1 & 2 & 1 & 0 & 1 & 2 & 0 & 0 & 1 \\
\hline $\mathbf{2 0 0 5}$ & 3 & 3 & 5 & 0 & 1 & 2 & 0 & 0 & 0 & 0 & 0 & 0 & 0 & 0 & 0 & 0 & 0 & 0 \\
\hline $\mathbf{2 0 0 6}$ & 1 & 4 & 5 & 0 & 1 & 1 & 0 & 0 & 0 & 0 & 0 & 0 & 0 & 0 & 0 & 0 & 0 & 0 \\
\hline $\mathbf{2 0 0 7}$ & 5 & 6 & 8 & 3 & 4 & 4 & 2 & 3 & 3 & 2 & 3 & 3 & 1 & 2 & 2 & 0 & 1 & 1 \\
\hline $\mathbf{2 0 0 8}$ & 0 & 2 & 3 & 0 & 0 & 0 & 0 & 0 & 0 & 0 & 0 & 0 & 0 & 0 & 0 & 0 & 0 & 0 \\
\hline $\mathbf{2 0 0 9}$ & 5 & 7 & 9 & 1 & 3 & 4 & 0 & 2 & 1 & 0 & 1 & 0 & 0 & 0 & 0 & 0 & 0 & 0 \\
\hline $\mathbf{2 0 1 0}$ & 6 & 8 & 8 & 5 & 4 & 3 & 3 & 3 & 3 & 2 & 1 & 1 & 0 & 1 & 1 & 0 & 1 & 1 \\
\hline $\mathbf{2 0 1 1}$ & 5 & 5 & 6 & 2 & 3 & 4 & 1 & 2 & 3 & 1 & 1 & 3 & 0 & 1 & 2 & 0 & 1 & 1 \\
\hline $\mathbf{2 0 1 2}$ & 2 & 3 & 3 & 0 & 0 & 0 & 0 & 0 & 0 & 0 & 0 & 0 & 0 & 0 & 0 & 0 & 0 & 0 \\
\hline $\mathbf{2 0 1 3}$ & 3 & 4 & 4 & 1 & 1 & 3 & 0 & 0 & 0 & 0 & 0 & 0 & 0 & 0 & 0 & 0 & 0 & 0 \\
\hline $\mathbf{2 0 1 4}$ & 4 & 6 & 8 & 2 & 3 & 3 & 0 & 2 & 2 & 0 & 0 & 2 & 0 & 0 & 0 & 0 & 0 & 0 \\
\hline $\mathbf{2 0 1 5}$ & 6 & 7 & 8 & 4 & 4 & 4 & 2 & 4 & 4 & 2 & 1 & 1 & 1 & 0 & 0 & 1 & 0 & 0 \\
\hline $\mathbf{2 0 1 6}$ & 3 & 7 & 9 & 2 & 4 & 4 & 2 & 2 & 2 & 2 & 1 & 1 & 1 & 1 & 1 & 1 & 1 & 1 \\
\hline $\mathbf{2 0 1 7}$ & 4 & 5 & 5 & 2 & 1 & 2 & 1 & 1 & 1 & 0 & 1 & 1 & 0 & 0 & 0 & 0 & 0 & 0 \\
\hline $\mathbf{2 0 1 8}$ & 6 & 7 & 8 & 4 & 3 & 4 & 0 & 2 & 2 & 0 & 0 & 1 & 0 & 0 & 0 & 0 & 0 & 0 \\
\hline SUM & 74 & 103 & 121 & 41 & 49 & 57 & 18 & 27 & 32 & 12 & 12 & 17 & 5 & 7 & 9 & 3 & 5 & 5 \\
\hline
\end{tabular}

Table 4. Number of exceedances of the rainfall intensity set by Šamaj and Valovič for the observed years in Košice station.

\begin{tabular}{|r|r|r|r|r|r|r|r|r|r|r|r|r|r|r|r|r|r|r|r|}
\hline $\begin{array}{l}\text { Periodicity } \\
\begin{array}{l}\text { Duration } \\
\text { (min)/Years }\end{array}\end{array}$ & $\mathbf{1 0}$ & $\mathbf{1 0}$ & $\mathbf{3 0}$ & $\mathbf{6 0}$ & $\mathbf{1 0}$ & $\mathbf{3 0}$ & $\mathbf{6 0}$ & $\mathbf{1 0}$ & $\mathbf{3 0}$ & $\mathbf{6 0}$ & $\mathbf{1 0}$ & $\mathbf{3 0}$ & $\mathbf{6 0}$ & $\mathbf{1 0}$ & $\mathbf{3 0}$ & $\mathbf{6 0}$ & $\mathbf{1 0}$ & $\mathbf{3 0}$ & $\mathbf{6 0}$ \\
\hline $\mathbf{2 0 0 3}$ & 5 & 5 & 6 & 1 & 3 & 4 & 1 & 0 & 1 & 1 & 0 & 0 & 0 & 0 & 0 & 0 & 0 & 0 \\
\hline $\mathbf{2 0 0 4}$ & 4 & 2 & 4 & 0 & 1 & 1 & 0 & 0 & 0 & 0 & 0 & 0 & 0 & 0 & 0 & 0 & 0 & 0 \\
\hline $\mathbf{2 0 0 5}$ & 4 & 5 & 5 & 1 & 2 & 4 & 1 & 2 & 2 & 0 & 1 & 2 & 0 & 1 & 1 & 0 & 1 & 1 \\
\hline $\mathbf{2 0 0 6}$ & 6 & 5 & 6 & 3 & 5 & 5 & 2 & 2 & 1 & 1 & 1 & 1 & 0 & 0 & 1 & 0 & 0 & 0 \\
\hline $\mathbf{2 0 0 7}$ & 3 & 5 & 6 & 3 & 2 & 4 & 1 & 1 & 1 & 0 & 1 & 1 & 0 & 1 & 1 & 0 & 1 & 1 \\
\hline $\mathbf{2 0 0 8}$ & 2 & 2 & 3 & 1 & 2 & 2 & 1 & 1 & 2 & 1 & 1 & 2 & 1 & 1 & 1 & 0 & 1 & 1 \\
\hline $\mathbf{2 0 0 9}$ & 0 & 3 & 6 & 0 & 0 & 0 & 0 & 0 & 0 & 0 & 0 & 0 & 0 & 0 & 0 & 0 & 0 & 0 \\
\hline $\mathbf{2 0 1 0}$ & 2 & 5 & 7 & 1 & 2 & 2 & 1 & 1 & 0 & 0 & 0 & 0 & 0 & 0 & 0 & 0 & 0 & 0 \\
\hline $\mathbf{2 0 1 1}$ & 7 & 7 & 7 & 3 & 2 & 2 & 2 & 2 & 1 & 2 & 0 & 0 & 0 & 0 & 0 & 0 & 0 & 0 \\
\hline $\mathbf{2 0 1 2}$ & 3 & 5 & 8 & 2 & 1 & 2 & 0 & 1 & 1 & 0 & 1 & 0 & 0 & 0 & 0 & 0 & 0 & 0 \\
\hline $\mathbf{2 0 1 3}$ & 4 & 5 & 5 & 1 & 1 & 3 & 0 & 0 & 1 & 0 & 0 & 0 & 0 & 0 & 0 & 0 & 0 & 0 \\
\hline $\mathbf{2 0 1 4}$ & 3 & 4 & 7 & 2 & 3 & 5 & 1 & 2 & 3 & 1 & 0 & 1 & 0 & 0 & 0 & 0 & 0 & 0 \\
\hline $\mathbf{2 0 1 5}$ & 4 & 6 & 5 & 3 & 2 & 2 & 2 & 2 & 2 & 1 & 1 & 2 & 1 & 1 & 1 & 1 & 1 & 1 \\
\hline $\mathbf{2 0 1 6}$ & 5 & 5 & 6 & 4 & 5 & 5 & 3 & 4 & 3 & 2 & 2 & 3 & 1 & 1 & 2 & 1 & 0 & 0 \\
\hline $\mathbf{2 0 1 7}$ & 0 & 1 & 4 & 0 & 0 & 0 & 0 & 0 & 0 & 0 & 0 & 0 & 0 & 0 & 0 & 0 & 0 & 0 \\
\hline $\mathbf{2 0 1 8}$ & 4 & 7 & 8 & 1 & 2 & 2 & 1 & 1 & 1 & 0 & 1 & 1 & 0 & 1 & 1 & 0 & 1 & 1 \\
\hline SUM & 56 & 72 & 93 & 26 & 33 & 43 & 16 & 19 & 19 & 9 & 9 & 13 & 3 & 6 & 8 & 2 & 5 & 5 \\
\hline
\end{tabular}


In the Table 3 and Table 4, there are numbers of exceedances of the rainfall intensities set by Šamaj and Valovič in observed years. Globally we can say that in recent years, rains with the intensity set by Šamaj and Valovič have been more frequent, as reported in their work from 1973, especially for rains with longer durations (30 minutes and 60 minutes). More often, these intensities are exceeded at the Poprad station (Table 3), which is due to the fact that the intensity values for the Poprad station are significantly lower than in the Košice station. For designing of rainwater sewage system is the most important rain with short duration (10 and 30 minutes) and with periodicity 0.2 (highlighted in Table 3 and Table 4). It means the occurrence of rain with an intensity higher than the tabular value once every 5 years. In Poprad station (Table 3) there is 19 years of observations, which means, that rain with periodicity 0.2 should occur 4 times. The results showed that rain with a duration of 10 minutes and a periodicity of 0.2 exceeded the intensities set by Šamaj and Valovič at the Poprad station 5 times in total, rain with a duration of 30 minutes 7 times in total and rain with a duration of 60 minutes 9 times in total. A periodicity 0.2 means that rain with a set intensity according to Šamaj and Valovič should occur 4 times. This means that the occurrence of such rain has been significantly exceeded. It is also similar in Košice station (Table 4), especially for rain with duration 30 and 60 minutes. From the above results it is clear that the calculation of rainfall intensity for the territory of Slovakia is not so accurate and it would be necessary to update the values of the design intensity according to the currently available data. It would also be necessary to verify the validity of this conclusion also on data from other rainfall stations.

\section{Conclusion}

Many of scientific publications have shown that climate change affects the temporal and spatial distribution of precipitation. The values of rainfall intensities from 1973, which have been almost 50 years old are still used in Slovakia. The results of this paper show that the intensities which are currently in use are not satisfactory, especially for precipitation with a duration of more than 30 minutes. In almost all periodicities, exceedances were observed in the number of observed precipitations with a design rainfall intensity. The results show that the rainfall intensity would need to be updated according to currently available data.

For short-term rainfall, the geographical location is not important, as it can occur anywhere in the country. For this reason, it seems more appropriate to divide Slovakia into large areas, eg. only four regions, for example according to annual rainfall, for which the rainfall intensities would be set for the calculation of the design rainfall. The aim of this article was to evaluate the measured data and verify the hypothesis that climate change affects rainfall intensities also in Slovakia, which was partially confirmed.

Thanks to the support of project SK-PL-18-0033 by Slovak Research and Development Agency.

\section{References}

1. A. Al-Dokhayel, BS Project (Civil Engineering Department, King Saud University, Riyadh (KSA), 1986)

2. O. Dub, J. Němec, Hydrologie (Nakladatelství technické literatury, Praha, 1969)

3. V. Te Chow, Applied hydrology (Tata McGraw-Hill Education, 2010)

4. S. Fadhel, M. A. Rico-Ramirez, D. Han, J. Hydrol 547, 600-612, (2017) 
5. O. Dub, Hydrológia, hydrografia, hydrometria (Slovenské vydavatel'stvo technickej literatúry, 1957)

6. P. Urcikán, D. Rusnák, Stokovanie a čistenie odpadových vôd: stokovanie I. Navrhovanie stokových sietí (Slovenská technická univerzita, Bratislava, 2004)

7. A. Repel, IOP Conf. Ser. Mater. Sci. Eng 566, 1 (2019)

8. F. Šamaj, Š. Valovič, Intensities of short-term rainfall in Slovakia (Proceedings of works of HMI, 1973)

9. P. Urcikán, L. Imriška, Sewage systems and waste water treatment-tables for calculations of pipeline dimensions (ALFA/SNTL, Bratislava, 1986)

10. P. Faško, M. Lapin, P. Št’astný, J. Vivoda, Prace Geo.-Zesz 108, 131-138 (2000)

11. E. Cebulak, P. Faško, M. Lapin, P, Prace Geo 108, 117-124 (2000)

12. S. Kohnová, L. Gaál, J. Szolgay, K. Hlavčová, Analýza maximálnych úhrnov zrážok v povodí horného Hrona (Slovenská technická Univerzita, Bratislava, 2006)

13. M. Brunetti, M. Colacino, M. Maugeri, T. Nanni, Int. J. Climatol 21, 3, 299-316 (2001)

14. D. Y. Gong, P. J. Shi, J. A. Wang, J. Arid Environ 59, 4, 771-784 (2004)

15. V. Jankovská, Folia Geobot. Phytotax 23, 303-319 (1988)

16. L. Miklós, Landscape atlas of the Slovak Republic (Bratislava, 2002) 